\title{
PENGARUH STRUKTUR AKTIVA, PROFITABILITAS, UKURAN PERUSAHAAN, DAN LIKUIDITAS TERHADAP STRUKTUR MODAL PADA PERUSAHAAN MANUFAKTUR, TAHUN 2014-2018
}

\author{
Alphonsius Umbu Manja ${ }^{1}$ \\ Eka Putri Suryantari ${ }^{2}$ \\ Program Studi Manajemen, Fakultas Ekonomika dan Humaniora, \\ Universitas Dhyana Pura, Bali, Indonesia ${ }^{1}$ \\ email: ekaputrisuryantari@undhirabali.ac.id
}

\begin{abstract}
This study aims to determine how the influence of asset structure, profitability, company size, and liquidity on capital structure partially or simultaneously. The data used in this study were taken from financial reports that can be accessed on the Indonesia Stock Exchange (IDX) or www.idx.co.id and their respective websites from the manufacturing companies in the cosmetics and household equipment subsector. Sampling uses a purposive sampling technique and gets the results of 5 company samples that fit the research criteria. The analysis technique used is multiple linear regression analysis. The results of this study indicate that partially the asset structure has no significant effect on the capital structure with the calculated $T$ calculation value of 1.664, and a significant value of 0.112, profitability has a significant effect on the capital structure with the calculation result of the calculated $T$ value of -3.720 and a significant value of 0.001 , company size has a significant effect on capital structure with the calculated $T$ value of 2,950 and a significant value of 0.008, and the liquidity has a significant effect on the capital structure with a calculated $T$ value of $-8,082$ and a significance value of 0,000 . While the simultaneous structure of assets, profitability, company size, and liquidity have significant effect on capital structure with the calculated $F$ calculation of 34.620 and a significant value of 0.000 .
\end{abstract}

Keywords: $\quad$ asset structure, profitability, company size, liquidity, capital structure.

\section{PENDAHULUAN}

Setiap perusahaan yang baru memulai membuka usaha maupun yang sedang menjalankan usahanya akan membutuhkan modal yang mencukupi namun kadangkala perusahaan menemui permasalahan yaitu tidak mampu memenuhi apa yang menjadi kebutuhan dananya . Brigham dan Houston $(2011 ; 153)$ menyebutkan bahwa pada sebuah usaha milik seseorang yang masih berkembang pemenuhan kebutuhan dananya dilakukan dengan berhutang kepada pihak lain Pada penelitian ini struktur modal dilihat dari Debt to Equity Ratio atau disingkat DER. Makin tinggi DER suatu perusahaan mengisyaratkan makin tingginya sebuah utang pada sumber milik seseorang.

Saat ini, khususnya perusahaan kosmetik dan keperluan rumah tangga perusahaan dituntut untuk menyiapkan strategi dalam menghadapi persaingan yang sangat ketat. Oleh karena perusahaan harus benar-benar 
menjalankan fungsi dalam perusahaan tersebut seperti fungsi produksi, fungsi penjualan, fungsi pemasaran, fungsi keuangan dan fungsi personalia perusahaan, agar perusahaan dapat bersaing dan unggul dari perusahaanperusahaan lain.

Struktur aktiva adalah sebuah variabel yang amat penting dalam memutuskan dana dari usaha milik seseorang dikarenakan memiliki hubungan serta pemrosesan dalam reproduksi sebuah usaha milik seseorang dalam memperoleh peningkatan laba usaha . Makin tinggi aktiva yang dimiliki maka semakin mampu memberikan laba yang optimal.

Menurut Sudana (2011;22), menjelaskan bahwa profitabilitas adalah sebuah kemampuan dari usaha milik seseorang yang mampu memberikan sebuah laba dengan menggunakan sumber dana yang dipunyai oleh usaha milik seseorang..Ukuran profitabilitas memakai ROA ( Return on Asset) yang merupakan perbandingan antara laba dengan asset perusahaan. .Menurut Sudana $(2011 ; 22)$, semakin tinggi ROA maka makin efisien penggunaan aktiva perusahaan dalam menghasilkan laba.

Menurut Riasita (2014:22), pengukuran dalam usaha milik seseorang yaitu sebuah deskripsi dalam menggambarkan kemampuan finansial dari usaha milik seseorang pada periode tertentu. Usaha dari finansialnyadiperhatikan

padabeberapa sisi yang mampu terlihat pada penjualani serta penjumlahan dari sebuah aktiva yang dimiliki.

Menurut Sudana (2011;21) menyebutkan bahwa likuiditas dapat diukur menggunakan current ratio, dimana perhitungnnya berasal dari aktiva lancar dibagi utang lancar. Artinya seberapa banyak aktiva lancar perusahaan dibiayai dari hutang lancarnya. Menurut Fahmi $(2012 ; 69)$ semakin tinggi nilai current ratio maka semakin bagus perusahaan tersebut.

Penelitian ini dilakukan pada perusahaan kosmetik dan keperluan rumah tangga tanggakarena jenis perusahaan ini mampu bertahan seperti situsi krisis ekonomi seperti saat ini dimana sektor yang lainnya mengalami penurunan di tengah krisis global yang melanda ekonomi dunia.

\section{METODE PENELITIAN}

Lokasi penelitian ini dilaksanakan di Bursa Efek Indonesia (BEI) dengan menggunakan situs resmi yaitu link www.idx.co.id. Penelitian ini menggunakan data kuantitatif dan data kualitatif . Data kuantitatif yaitu data numerik atau data pada bentukan sebuah angka dari laporan posisi keuangan maupun laba rugi. Sedangkan data kualitatif merupakan data informasi berbentuk kalimat verbal yang berisi informasi gambaran umum, sejarah dan kendalakendala yang muncul dalam usaha mencapai return saham yang baik.

Populasi dalam penelitian ini adalah perusahaan manufaktur sektor produk kosmetik dan rumah tangga yang ada di Bursa Efek Indonesia (BEI) Tahun 2014-2018 sebanyak 6 perusahaan. Penelitian ini menggunakan teknik purposive sampling (Sugiyono, 2014;122) dan yang memenuhi kriteria sebanyak 5 perusahaan.

Adapun definisi operasional masing - masing variabel sebagai berikut :

1) Struktur permodalan adalah dalam hutang dalam jangka panjangnya serta ekuitas dalam menentukan 
jenis sekuritas yang dikeluarkan. Struktur permodalan diukur dengan DER sebagai berikut, Brigham dan Houston (2011)

$$
\text { DER }=\frac{\text { Totalhutang }}{\text { Totalekuitas }} \times 100 \%
$$

2) Struktur aktiva adalah perbandingan antara aktiva tetap dengan total suatu perusahaan, rumusnya sebagai berikut, Riyanto $(2011 ; 22)$ :

$$
S A=\frac{\text { Aktivatetap }}{\text { Totalaktiva }}
$$

3) Profitabilitas adalah sebuah kemampuan perusahaan dalam menghasilkan laba dengan menggunakan sumber daya yang dimiliki perusahaan Ukuran profitabilitas menggunakan ROA rumusnya sebagai berikut Sartono $(2012 ; 113)$ :

$$
=\frac{\text { ROA }}{\text { Lababersihsetelahpajak }}
$$

4) Ukuran perusahaan merupakan gambaran besar kecilnya perusahaan yang ditinjau dari lapangan usaha yang dijalankan ,Nadeem dan Wang $(2011 ; 124)$ Ukuran perusahaan $=$ Ln (total aktiva)

5) Likuiditas yang pengukurannya menggunakan current ratio yang menyatakan seberapa banyak hutang lancar dijamin oleh aktiva lancar dengan rumus sebagai berikut, Kasmir (2016;135) :

$$
\text { Currentratio }
$$

$$
=\frac{\text { Aktivalancar }}{\text { Utanglancar }} \times 100 \%
$$

Teknik analisis data memakai analisis regresi linier berganda, dengan persamaan berikut ini $Y=\alpha+\beta_{1} X_{1}+\beta_{2} X_{2}+\beta_{3} X_{3}+\beta_{4} X_{4}+e$

\section{HASIL DAN PEMBAHASAN UjiAsumsiKlasik}

Tabel 1

Hasil Uji Normalitas

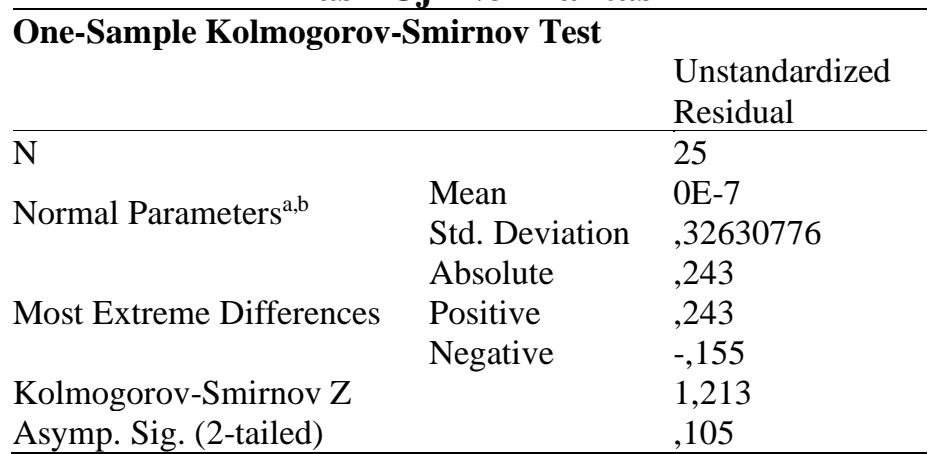

Sumber: Data diolah (2020)

Mengacu pada hasi lpenguujian normalitasnya menggunakan metodeOne-Sample Kolmogorov-Smirnov Tests nilai 1,213 denga nilai Asymp.Sig (2-tailed) senilai 0,105 >0,05 mengartikan data terdistribusi dengan normal. 


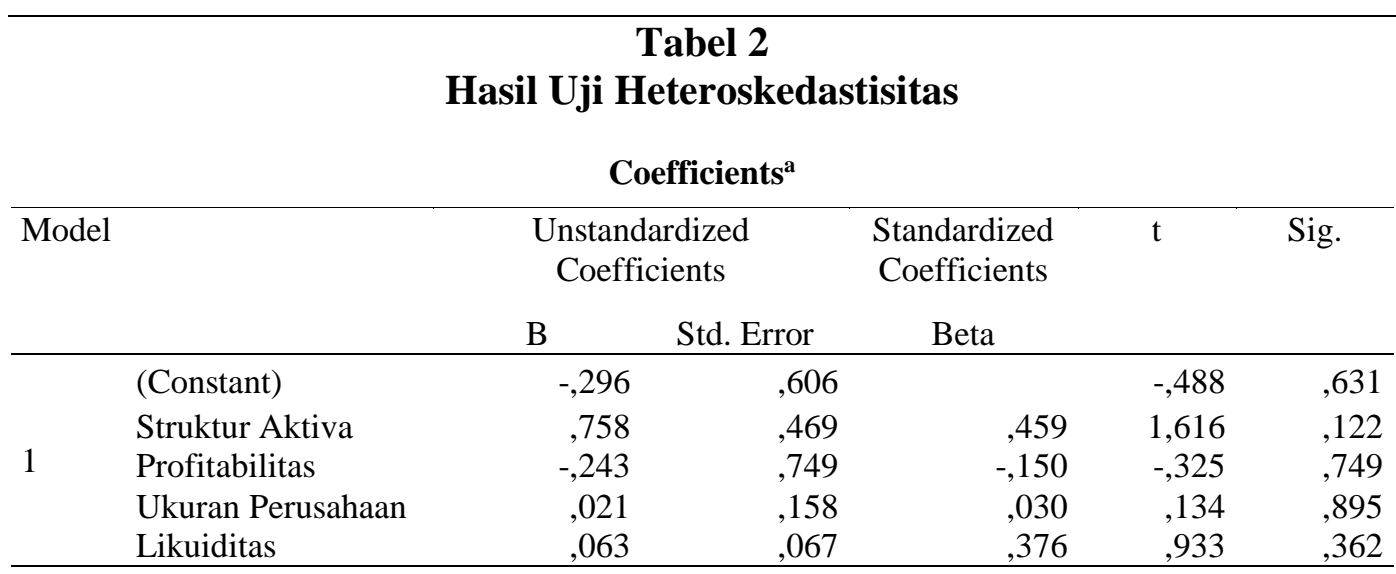

Sumber : Data diolah,2020

Mengacu pada uji ukuran usaha, serta 0,362 untuk heteroskedastisitas, dimana nilai likuiditasnya. Nilai signifikan semua signifikannyavariabel bebas sebesar variabel melebihi nilai alphanya $(\alpha)$ 0,122 untuk variabel struktur $5 \%(0,05)$.sehingga tidak terjadi aktivanya, $\quad 0,749$ heteroskedastisitas. untukProfitabilitasnya, 0,895 untuk

Tabel 3

Hasil Uji Autokorelasi

Model Summary ${ }^{\mathrm{b}}$

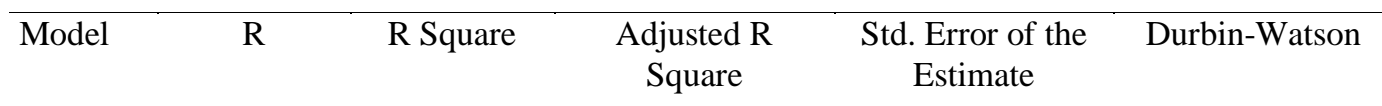

\begin{tabular}{llllll}
\hline 1 &, $935^{\text {a }}$ &, 874 &, 849 &, 35745 & 1,940 \\
\hline
\end{tabular}

Sumber :Data diolah (2020)

Mengacu pada Tabel bahwa nilai D-W (Durbin Watsonnya) senilai 1,940. Yang mana nilainyadU (Durbin Upper) pada penelitian ini yaitu $\mathrm{dU}=$ 1,7666 , DW $=1,940$, dan $(4-\mathrm{dU})=$ 2,2334 maka diperoleh hasil 1,7666 < $1,940<2,2334$. Mengartikan tidak terjadinyaautokorelasi.

\section{Hasil Uji Multikolinieritas}

Mengacu pada hasil uji multikolinieritas dapat diketahui bahwa koefisien VIF berkisardari 1,209 s.d. 5,152 dimana< 10 dan nilai Tolerancenya berkisardari 0,194 s.d. 0,827 dimana $>0,10$. Mengartikan 
Journal of Applied Management and Accounting Science ( J A M A S )

(Alphonsius Umbu Manja, Eka Putri Suryantari 12 - 22)

Vol 2, No 1, Desember 2020

\section{Tabel 4}

\section{Hasil Analisis Regresi Linear Berganda}

Coefficients $^{\text {a }}$

\begin{tabular}{|c|c|c|c|c|c|c|}
\hline \multirow{2}{*}{\multicolumn{2}{|c|}{ Model }} & \multicolumn{2}{|c|}{$\begin{array}{l}\text { Unstandardized } \\
\text { Coefficients }\end{array}$} & \multirow{2}{*}{$\begin{array}{c}\text { Standardized } \\
\text { Coefficients } \\
\text { Beta }\end{array}$} & \multirow[t]{2}{*}{$\mathrm{t}$} & \multirow[t]{2}{*}{ Sig. } \\
\hline & & $\mathrm{B}$ & Std. Error & & & \\
\hline \multirow{5}{*}{1} & (Constant) & 3,657 & ,830 & & 4,405 &, 000 \\
\hline & Struktur Aktiva & 1,069 & ,642 &, 184 & 1,664 & ,112 \\
\hline & Profitabilitas & $-3,817$ & 1,026 &,- 671 & $-3,720$ & 001 \\
\hline & Ukuran Perusahaan &,- 639 & 217 &,- 258 & $-2,950$ & ,008 \\
\hline & Likuiditas &,- 743 & ,092 & $-1,271$ & $-8,082$ &, 000 \\
\hline
\end{tabular}

a. Dependent Variable: Struktur Modal

Sumber : Data diolah, 2020

Pada analisis sebuah regresi $\quad \mathrm{Y}=3,657+1,069 \mathrm{X}_{1}-3,817 \mathrm{X}_{2}$ liniernya maka persamaanya $0,639 \mathrm{X}_{3}-0,743 \mathrm{X}_{4}+\mathrm{e}$ membentuk sebuah persamaan

Uji Hipotesis

Tabel 5

Hasil Uji T-test

Coefficients $^{\mathrm{a}}$

\begin{tabular}{llrrrrr}
\hline Model & & \multicolumn{2}{c}{$\begin{array}{c}\text { Unstandardized } \\
\text { Coefficients }\end{array}$} & $\begin{array}{l}\text { Standardized } \\
\text { Coefficients }\end{array}$ & t & Sig. \\
& & B & Std. Error & Beta & & \\
\hline \multirow{2}{*}{1} & (Constant) & 3,657 &, 830 & & 4,405 &, 000 \\
& Struktur Aktiva & 1,069 &, 642 &, 184 & 1,664 &, 112 \\
& Profitabilitas & $-3,817$ & 1,026 &,- 671 & $-3,720$ &, 001 \\
& Ukuran Perusahaan &,- 639 &, 217 &,- 258 & $-2,950$ &, 008 \\
& Likuiditas &,- 743 &, 092 & $-1,271$ & $-8,082$ &, 000 \\
\hline
\end{tabular}

a. Dependent Variable: Struktur Modal

Sumber: Data diolah (2020)

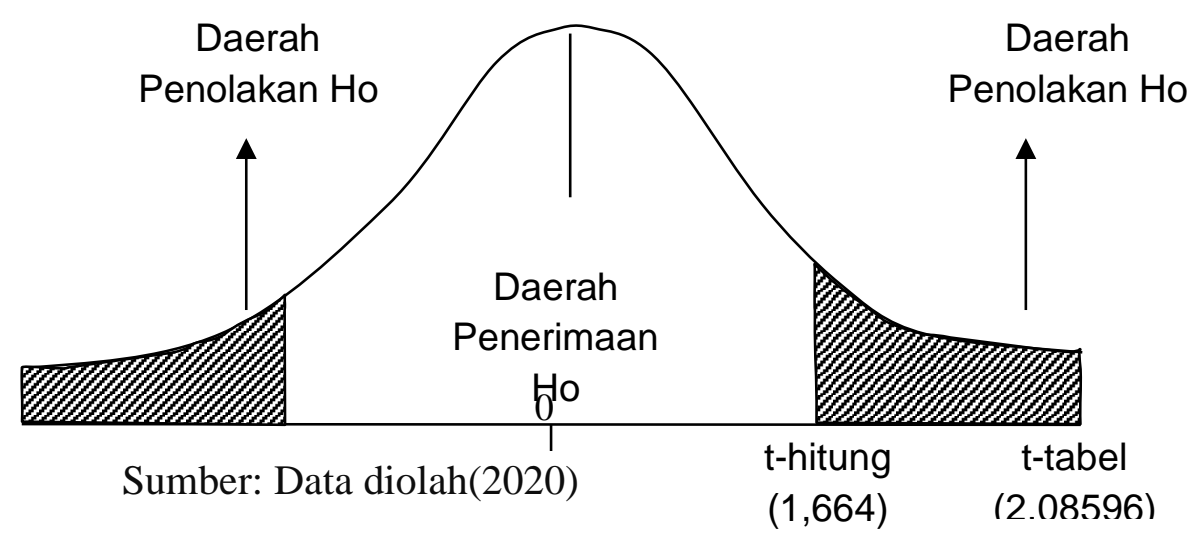

Gambar1

Kurva Distribusi Normal Uji T-test 
Mengacu pada analisis t-test dan gambar di atas terlihat thitungnya yaitu 1,664 sedangkan $t$ tabelnya 2,08596 dengan tingkat signifikannya $0,112>0,05$ dengan penerimaan $\mathrm{H}_{0}$ berarti $\mathrm{H}_{0}$ diterima, maka penolakan Ha sehingga secara parsial struktur aktiva tidak punya pengaruh yang signifikan secara positif kepada struktur modalnya.

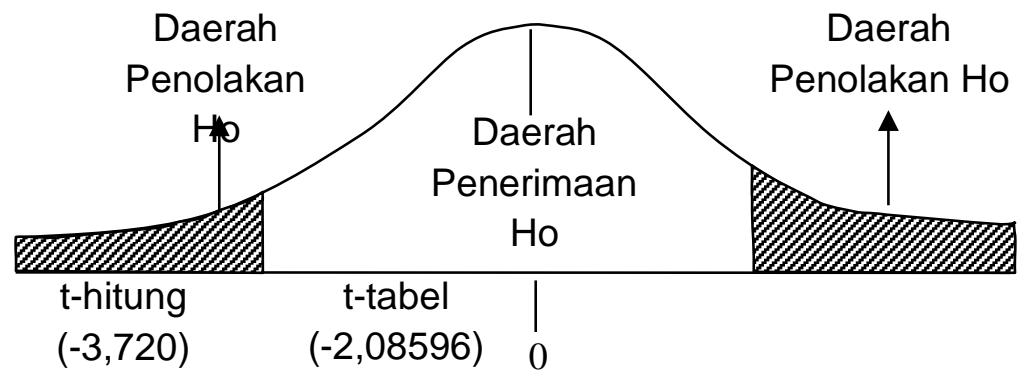

Sumber: Data diolah (2020)

\section{Gambar 2}

\section{Kurva Distribusi Normal Uji t}

Mengacu pada analisis $t$-test dan gambar di atas terlihat $t$ hitungnyayaitu-3,817 sedangkan ttabelnya-2,08596 dengan tingkat signifikannya $0,001<0,05$ dengan penolakan $\mathrm{H}_{0}$, makapenerimaan $\mathrm{Ha}$ maka hasil ini mempunyai arti bahwa secara parsial profitabilatas punya pengaruh yang signifikan secara positif kepada struktura modalnya.

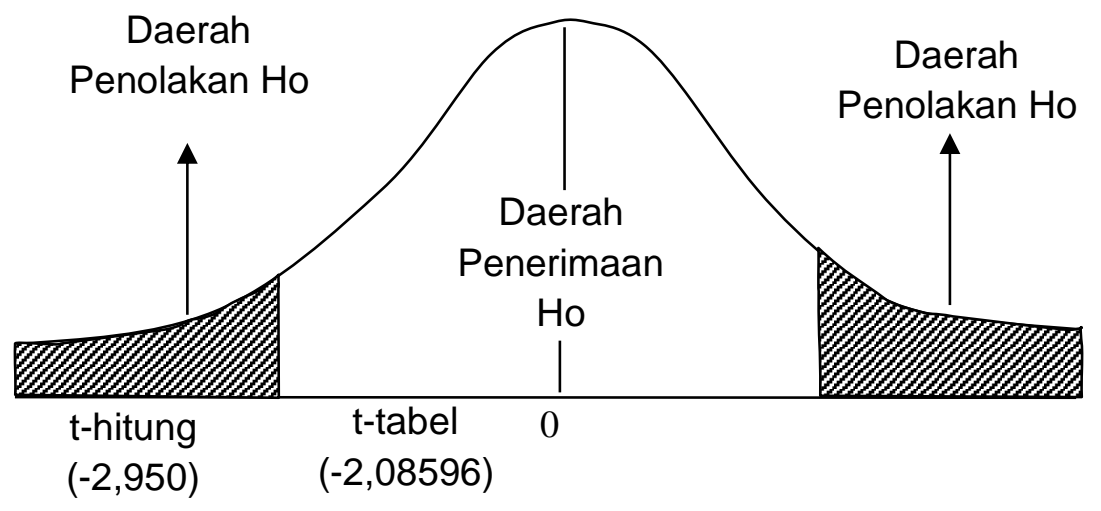

Sumber: Data diolah (2020)

\section{Gambar3}

\section{Kurva Distribusi Normal Uji T-test}

Mengacu pada analisis t-test dan gambar di atas terlihat $t$ hitungnya yaitu--2,950 sedangkan t-tabelnya2,08596 dengan tingkat signifikannya $0,008<0,05$ dengan penolakan $\mathrm{H}_{0}$, maka penerimaan Ha maka hasil ini mempunyai arti bahwa secara parsial ukuran dari perusahaannya punya pengaruh yang signifikan secara positif kepada struktur modalnya 


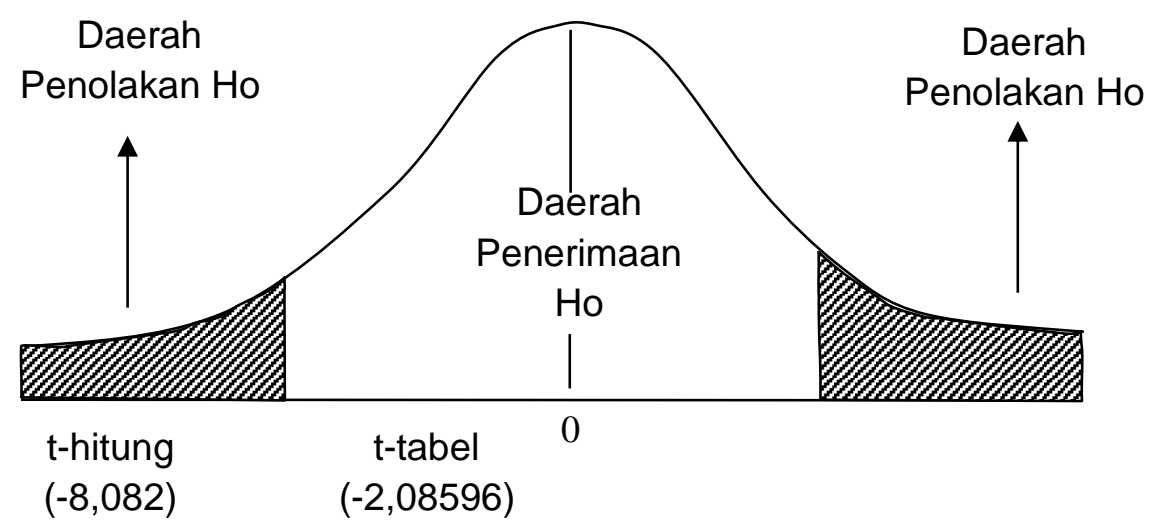

Sumber: Data diolah (2020)

\section{Gambar4 \\ Kurva Distribusi Normal Uji T-test}

Mengacupada analisis t-test dan gambar di atas terlihat $t$ hitungnyayaitu---8,082 sedangkan ttabelnya $-2,08596$ dengan tingkat signifikannya $0,000<0,05$ dengan penolakan $\mathrm{H}_{0}$, makapenerimaan $\mathrm{Ha}$ maka hasil ini mempunyai arti bahwa secara parsial likuiditasnya perusahaan berpengaruh signifikan secara positif kepada struktur modalnya.

\section{Tabel 6}

Uji F-test

ANOVA $^{a}$

\begin{tabular}{llrrrrr}
\hline Model & & Sum of Squares & Df & Mean Square & F & Sig. \\
\hline \multirow{3}{*}{1} & Regression & 17,694 & 4 & 4,423 & 34,620 &, $000^{\mathrm{b}}$ \\
& Residual & 2,555 & 20 &, 128 & & \\
& Total & 20,249 & 24 & & & \\
\hline
\end{tabular}

Sumber: Data diolah (2020)

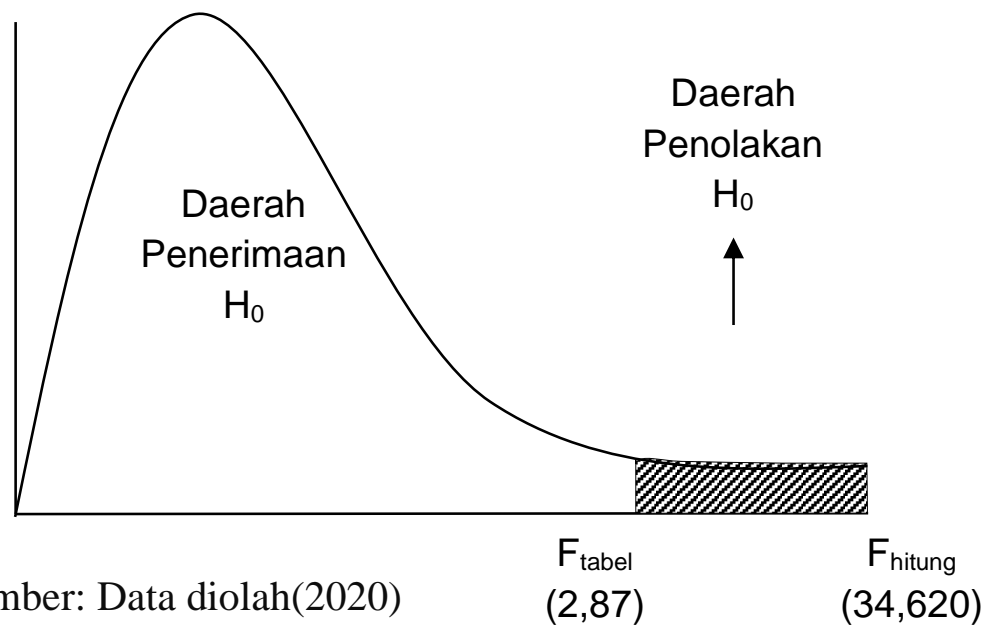

Gambar 4.5

Kurva Distribusi Normal Uji F-test 


\begin{abstract}
Berdasarkan analisis $f$-test dan gambar di atas terlihat bahwa nilai fhitung adalah 34,620 sedangkan ftabel 2,87 dengan tingkatan signifikannya $0,000<0,05$ sehingga $\mathrm{f}$ hitungnya penerimaan $\mathrm{H}_{\mathrm{a}}$. Hasil ini mempunyai arti bahwa secara simultan
\end{abstract}

structural aktivanya, profitabilitasnya, ukuran perusahaannya serta likuiditasnya punya pengaruh signifikan kepada struktural modalnya Koefesien Determinasi (Adjusted $\mathbf{R}^{2}$ )

Tabel7

UjiKoefesienDeterminasi

\begin{tabular}{lrrrrr}
\multicolumn{5}{c}{ Model Summary } \\
\hline Model & R & R Square & $\begin{array}{c}\text { Adjusted R } \\
\text { Square }\end{array}$ & $\begin{array}{c}\text { Std. Error of the } \\
\text { Estimate }\end{array}$ \\
\hline 1 &, $935^{\mathrm{a}}$ &, 874 &, 849 &, 35745 \\
\hline
\end{tabular}

Sumber: Data diolah (2020)

Mengacu pada tabel nilai koefesiennya yang didapat adalah senilai 0,849.Nilai dari determinasi nya menjadi $0,849 \times 100 \%=84,90 \%$ berarti struktural modal mampu dijelaskan sebesar 84,90\% oleh variabel struktural aktivanya, ROA, ukuran dari sebuah perusahaan sertacurrent rationya, sedangkan sisanyasebesar $15,10 \% \quad(100 \% \quad$ $84,90 \%=15,10 \%)$ dijelaskan oleh faktor lainnya.

\section{Pengaruh Struktur Aktiva Kepada Struktur Modal}

Mengacu pada analisis t-test dan gambar di atas terlihat $t$ hitungnya yaitu1,664 sedangkan t-tabelnya 2,08596 dengan tingkat signifikannya $0,112>0,05$ dengan penerimaan $\mathrm{H}_{0}$ berarti $\mathrm{H}_{0}$ diterima, maka penolakan Ha maka hasil ini mempunyai arti bahwa secara parsial Struktur Aktiva tidak punyapengaruh yang signifikan secara positif kepada struktur modalnya.

Hal itu disebabkan karena perusahaan yang diteliti konstan memakai dana internal yang membuat beberapa perusahaan tidak perlu melakukan pendanaan melalui hutang. Dengan kata lain perusahaan mampu melakukan kegiatan investasi dan melanjutkan kegiatan operasi perusahaan tanpa menggunakan hutang. Hasil penelitian ini diperkuat oleh Santika dan Sudiyanto (2011) yang menunjukkan struktur aktiva tidak ber pengaruh positif dan signifikan kepada struktur modalnya. Pengaruh Profitabilitas Kepada Struktur Modal

Profitabilitas perusahaan adalah kemampuan perusahaan dalam menghasilkan laba. Mengacu pada analisis t-test dan gambar di atas terlihat $\mathrm{t}$ hitungnya yaitu-3,817 sedangkan t-tabelnya-2,08596 dengan tingkat signifikannya $0,001<0,05$ dengan penolakan $\mathrm{H}_{0}$, maka penerimaan $\mathrm{Ha}$ maka hasil ini mempunyai arti bahwa secara parsial profitabilatas perusahaan yang diteliti berpengaruh signifikan secara positif kepada struktur modalnya. Perusahaan tersebut tidak akan bergantung pada pihak eksternal yaitu berupa hutang karena tingkat profitabilitas perusahaan yang tinggi akan membuat perusahaan tersebut mendapatkan sebagian besar modal pendanaanya berasal dari internal perusahaan berupa laba ditahan. Ini terjadi karena 
semakin tinggi keuntungan dari sebuah perusahaan maka sumber dari sebuah dana yang didapat berasal dari internal perusahaannya.Hasil penelitian ini konsisten dengan penelitian khariry dan yusniar (2016) yang membuktikan bahwa profitabilitas berpengaruh yang negatif serta signifikan terhadap struktur modalnya.

\section{Pengaruh Ukuran Perusahaan Kepada Struktur Modal}

Mengacu pada analisis t-test dan gambar di atas terlihat t hitungnya yaitu--2,950 sedangkan t-tabelnya2,08596 dengan tingkat signifikannya $0,008<0,05$ dengan penolakan $\mathrm{H}_{0}$, maka penerimaan Ha maka hasil ini mempunyai arti bahwa secara parsial ukuran dari perusahaannya punya pengaruh yang signifikan secara positif kepada Struktural Modalnya.

Ukuran Perusahaan akan berpengaruh terhadap nilai jual dan laba yang tinggi. Besarnya jumlah laba akan membantu perusahaan untuk memenuhi modalnya dari sumber internal atau dari laba tersebut sehingga jumlah hutang perusahaan menjadi sedikit. Hasil penelitian ini sesuai dengan penelitian Hadianto, Fayana (2010) menunjukkanbahwa ukuran perusahaannya punya pengaruh yang negatif serta signifikan kepada struktural modalnya.

\section{Pengaruh Likuiditas Kepada Struktur Modal}

Mengacu pada analisis t-test dan gambar di atas terlihat thitungnya yaitu---8,082 sedangkan t-tabelnya 2,08596 dengan tingkatan signifikannya $0,000<0,05$ dengan penolakan $\mathrm{H}_{0}$, maka penerimaan $\mathrm{Ha}$ maka hasil ini mempunyai arti bahwa secara parsial likuiditas perusahaan berpengaruh signifikan secara positif kepada struktural modalnya.
Perusahaan dengan likuiditas

yang tinggi akan melakukan pendanaan dengan menggunakan dana dari perusahaan itu sendiri yaitu asset lancar perusahaan. Hasil penelitian ini sesuai dengan penelitian dari Lasut, Rate dan Raintung (2018) .

\section{Pengaruh Struktur Aktiva, Profitabilitas, Ukuran Perusahaan Dan Likuiditas Secara Simultan Kepada Struktur Modal}

Berdasarkan analisis $f$-test dan gambar di atas terlihat bahwa nilai $\mathrm{f}$ hitung adalah 34,620 sedangkan $\mathrm{f}$ tabel 2,87 dengan tingkatan signifikannya $0,000<0,05$ sehingga berada pada penerimaan $\mathrm{H}_{\mathrm{a}}$. Hasil ini berarti secara simultan struktur aktiva, profitabilitas, ukuran perusahaan serta likuiditas berpengaruh signifikan terhadap struktur modalnya.

\section{SIMPULAN DAN SARAN Simpulan}

Adapun simpulan dalam penelitian ini sebagai berikut:

1) Secara parsial struktur aktivanya tidak punya pengaruh yang signifikan secara positif kepada struktur modalnya. Mengacu pada analisis $t$-test dan gambar di atas terlihat $\mathrm{t}$ hitungnya yaitu 1,664 sedangkan t-tabelnya 2,08596 dengan tingkat signifikannya $0,112>0,05$ denganpenerimaan $\mathrm{H}_{0}$ berarti $\mathrm{H}_{0}$ diterima.

2) Secara parsial profitabilatasnya berpengaruh signifikan secara positif kepada struktur modalnya. Mengacu pada analisis $t$-test dan gambar di atas terlihat t hitungnya yaitu-3,817 sedangkan t-tabelnya2,08596 dengan tingkat signifikannya $0,001<0,05$ dengan penolakan $\mathrm{H}_{0}$, maka penerimaan Ha. Perusahaan tersebut tidak akan bergantung pada pihak eksternal 
yaitu berupa hutang karena tingkat profitabilitas perusahaan yang tinggi akan membuat perusahaan tersebut mendapatkan sebagian besar modal pendanaanya berasal dari internal perusahaan berupa laba ditahan. Ini terjadi karena semakin tinggi keuntungan dari sebuah perusahaan maka sumber dari sebuah dana yang didapat berasal dari internal perusahaannya.

3) Secara parsial ukuran dari perusahaannya punya pengaruh yang signifikan secara positif terhadap struktur modalnya. Mengacu pada analisis t-test dan gambar di atas terlihat t hitungnya yaitu--2,950 sedangkan t-tabelnya2,08596 dengan tingkat signifikannya $\quad 0,008<\quad 0,05$ sehingga $\mathrm{H}_{0}$ ditolak maka $\mathrm{Ha}$ diterima.

4) Secara parsial likuiditas dari perusahaan berpengaruh signifikan secara positif terhadap struktur modalnya. Mengacu pada analisis $t$-test dan gambar di atas terlihat $\mathrm{t}$ hitungnya yaitu-8,082 sedangkan t-tabelnya $-2,08596$ dengan tingkatan signifikannya $0,000<0,05$ dengan penolakan $\mathrm{H}_{0}$, maka penerimaan Ha.

5) Secara simultan struktur aktiva, profitabilitas, ukuran perusahaan serta likuiditas berpengaruh signifikan terhadap struktur modalnya. Berdasarkan analisis $f$ test dan gambar di atas terlihat bahwa nilai f hitung adalah 34,620 sedangkan $\mathrm{f}$ tabel 2,87 dengan tingkatan signifikannya $0,000<$ 0,05 dengan penolakan $\mathrm{H}_{0}$, maka penerimaan $\mathrm{Ha}$.

6) Mengacu pada tabel nilai koefesiennya yang didapat adalah senilai 0,849 . Nilai dari determinasinya menjadi $0,849 \mathrm{x}$ $100 \%=84,90 \%$. Hal ini mengidentifikasikan variabel struktur aktiva, ROA, ukuran perusahaan serta current ratio berkontribusi sebesar 84,90\% terhadap struktur modal perusahaan dan sisanya sebesar $15,10 \%$ bisa dijelaskan oleh variabel lainnya.

\section{Saran}

Adapun saran dalam penelitian ini adalah

1) Untuk meningkatkan struktur modal dan nilai perusahaan agar optimal para manajer keuangan perlu memperhatikan struktur aktivanya, profitabilitasnya, ukuran dari sebuah perusahaan serta likuiditas dalam kebijakan struktur modalnya.

2) Untuk penelitian selanjutnya bisa difokuskan pada faktor yang paling dominan mempengaruhi struktur modal namun menggunakan berbagai pengukuran. Asset perusahaan perlu dikelola secara optimal untuk mendukung kegiatan perusahaan sehingga laba optimal akan tercapai yang nantinya dapat memenuhi kebutuhan pendanaan perusahaan melalui pendanaan internal

\section{DAFTAR PUSTAKA}

Brigham dan Houston. 2001. 2011. 2014.Dasar-dasar Manajemen Keuangan, Buku 2 Edisi 11. Bandung: Salemba Empat

Hamidah, Iswara Diana, Mardiyati Umi. 2016. The Effects Of Profitabillity, Liquid, Growth Sales, Operating Leverage and Tangibility On Capital Structure (evidence from 
manufacture firm listed on Indonesia stock exchange in 2011-2014). Jurnal Riset Manajemen Sains Indonesia (JRMSI), Vol 7, No.1, 2016

Hartono, Jogiyanto. 2013. 2016. Teori Portofolio Dan Analisis Investasi. Edisi Kesepuluh. Yogyakarta: BPFE

Irawan, Arief. 2018. Pengaruh Profitabilitas, Likuiditas, Ukuran Perusahaan Dan Struktur Aktiva Terhadap Struktur Modal (Studi Kasus Pada Perusahaan Sektor Properti, Real Estate Dan Konstruksi Bangunan Yang Terdaftar Di Bursa Efek Indonesia). Skripsi. Jurusan Akuntansi FE.Yogyakarta: Islam Indonesia.

Lasut, Stenyverens J.D, Rate Paulina van, Raintung Michael Ch. Pengaruh Ukuran Perusahaan, Profitabilitas, dan Likuiditas Terhadap Struktur Modal Pada Perusahaan Otomotif Yang Terdaftar Di Bursa Efek Indonesia Periode 2012-2015. Jurnal EMBA, Vol 6, No.1, Januari 2018, Hal.11-20

Lessy, Devi Anggriyani. 2016. Pengaruh dari Ukuran sebuah Perusahaan, Likuid, Profitabillitas, Dan Struktur Aktiva Terhadap Struktur Modal Pada Perusahaan Manufaktur Yang Terdaftardi Bursa Efek Indonesia. Skripsi. Jurusan Manajemen FE. Yogyakarta: Negeri Yogyakarta.
Sholikhatun, Siti. Pengaruh sebuah Ukuran dari Perusahaan, Pertumbuhan sebuah Asset, dalam Risiko di bidang Bisnis, Profitabilitas serta Likuiditas Kepada Struktural Modal (Sektor Mining Yang Tercatat di BEI 2011-2015).Skripsi. Jurusan Manajemen FEB. Malang: Dian Nuswantoro.

Suad Husnan dan EnnyPudjiastuti. $2012 . \quad$ Dasar-dasar Manajementdi bidang Keuangan. Edisi Keenam dalam Cetakan Pertama. Jakarta : UPP STIM YKPKN.

Sugiyono. 2013. 2014. 2016. Metode Penelitian Kuantitatif serta Kualitatif, dan $R \& D$. Cetakan ke 24. Bandung : Alfabeta

www.idx.co.id, Diakses Tanggal 23 November 2019 